\title{
Employment Training Programs and Acculturation of Native Peoples in Canada's Northwest Territories
}

\author{
R.A. YOUNG ${ }^{1}$ and PETER MCDERMOTT ${ }^{1}$
}

(Received 28 August 1987; accepted in revised form 10 March 1988)

\begin{abstract}
Theories of cultural diffusion and acculturation specify the conditions under which new behaviour, norms, and values are adopted. Both education and employment in modern enterprises have been identified as highly conducive to acculturation. This paper focuses on formal employment training as a possible agent of cultural change among native peoples in Canada's Northwest Territories. It analyzes all job training programs administered by governments over the 1971-83 period, presenting systematic data on them for the first time. During this period, the official Canadian government position about northern development was that the needs of indigenous peoples were to prevail over resource exploitation. At the same time, northern residents were to be offered training so that they might benefit from economic development by taking part in the expanding wage economy. Hence, officially, native peoples were to have a "choice of futures" - to be enabled to combine elements of southern and northern ways of life or to choose freely between them. But choices may be subtly shaped. Here we examine the structure rather than the explicit content of job training programs. We show that most programs operated by governments have been delivered in such a way as to stimulate rapid acculturation among trainees, by requiring relocation, the use of English, and adherence to fixed schedules. In recent years, some shift in program structure has been evident, so that the programs are delivered in a manner that better accommodates northern indigenous cultures. This raises the perennial, thorny question of whether segmented and obvious cultural contact is preferable to diffuse and co-optive interaction.
\end{abstract}

Key words: Canadian North, Northwest Territories, employment training, acculturation, modernization, program implementation

RÉSUMÉ. Les théories de la diffusion culturelle et de l'acculturation précisent les conditions dans lesquelles sont adoptés de nouveaux comportements ainsi que de nouvelles normes et valeurs. L'éducation et l'emploi dans des entreprises modemes ont tous deux été identifiés comme d'importants facteurs menant à l'acculturation. Cet article s'intéresse à la formation institutionnelle pour l'emploi, en tant qu'agent éventuel du changement culturel chez les peuples indigènes des Territoires du Nord-Ouest au Canada. Il fait une analyse de tous les programmes gouvernementaux de formation pour l'emploi offerts de 1971 à 1983, en présentant pour la première fois des données systématiques sur ces programmes. Au cours de cette période, la position officielle du Canada sur le développement du Grand Nord faisait passer les besoins des peuples indigenes avant l'exploitation des ressources. En même temps, les habitants du Grand Nord devaient recevoir une formation, de façon à pouvoir bénéficier du développement économique en prenant part à l'économie salariée qui se développait. Officiellement donc, les peuples indigènes devaient pouvoir «choisir leur futur», en ayant la possibilité de combiner les éléments du mode de vie du Sud et du Nord, ou bien d'opter librement pour l'un d'eux. Mais les choix peuvent être influencés sans que ce soit évident. On examine ici la structure des programmes de formation pour l'emploi plutôt que leur contenu explicite. On montre que la plupart des programmes administrés par les gouvernements l'ont été de façon à stimuler une acculturation rapide chez les stagiaires, acculturation provoquée par le fait qu'ils devaient se déplacer, utiliser l'anglais et se soumettre à des horaires fixes. Au cours des dernières années, on a assisté à une légère modification dans la structure des programmes qui sont maintenant offerts de manière à mieux tenir compte des cultures indigènes du Grand Nord. Ce qui soulève à nouveau l'épineuse question de savoir si le contact culturel structuré et évident est préférable à l'interaction plus subtile fondée sur un choix mutuel.

Mots clés: Grand Nord canadien, Territoires du Nord-Ouest, formation pour l'emploi, acculturation, modernisation, mise en application des programmes

Traduit pour le journal par Nésida Loyer.

\section{INTRODUCTION}

As many Third World development plans foundered in the post-colonial era, there emerged a school of research that concentrated on how social and cultural patterns could inhibit economic change (Hoselitz, 1954, 1959; Shils, 1975). Much of this work was soon effectively criticized as ethnocentric in its notion of what development means, paternalistic if not racist in its tendency to contrast "traditional" and "modern" societies, and inadequate empirically (Willner, 1964; Gusfield, 1967; Hirschman, 1965). Nevertheless, some careful studies of " modernization" did document the power of various experiences and institutions to induce among individuals and groups the acceptance of new values, norms, and behaviour - that is, to promote acculturation (which is the more neutral and non-teleological term we prefer to employ here).

It was observed, for instance, that East Indian workers training in American steel mills did not only acquire technical knowledge: through the factory experience "they also assimilate a real understanding of the industrial way of life that almost all Americans absorb, almost by a process of osmosis, from the time we are born"' (Blickenstaff, 1966:300). Such impressionistic considerations led to the massive comparative study of thousands of individuals in six developing countries conducted by Inkeles and Smith (1974). They assumed that institutions could promote cultural change among those newly exposed to them and found that along with the mass media the most powerful agents of acculturation were industrial work experience and formal education. Acculturation could be subtly induced. The process could have little to do with the explicit content of work or study. In schools, for example, much of the learning can be incidental to the curriculum and classroom instruction: the formal organization, the regular sequence of ordered activities, the explicit rules, and the unstated network of norms - all are conducive to fostering new norms, values, and behaviour among students from different cultural backgrounds (Inkeles, 1974, 1983; Sack, 1974).

In Canada's North, the position of native peoples differs, of course, from that of new immigrants to industrialized countries and from that of majority populations of developing countries. But acculturation is a central issue, especially to native leaders who assert the fundamental right of "Fourth World" peoples collectively to define themselves and their future (Nunavut Constitutional Forum, 1983; Erasmus, 1977).

Cultural change has occurred among the indigenous peoples of the Northwest Territories (N.W.T.) for centuries, as a result of contacts with European and North American civilizations and as a consequence of their gradual integration into the cash economy through trade and wage labour. The subsistence economy is long gone. As Brody (1975:214) put it, "The life now regarded as traditional by contemporary Eskimos was founded on a mixed economy: there was hunting and there was trading."

'Department of Political Science, The University of Western Ontario, London, Ontario, Canada N6A 5C2

(C)The Arctic Institute of North America 
Nevertheless the indigenous peoples of the N.W.T. have retained many elements of a distinct culture. Most use native languages, collective decisions tend to be reached through consensus, elders and hunters still enjoy much respect, there is a strong preference for "country food" (and for sharing it), and while few families are nomadic, most are inclined to live in settlements and hamlets rather than in the larger towns (Hobart, 1982).

Such traits are under constant pressure, both internal and external. The most important of the latter has been through the discovery and exploitation of new resources in the Canadian Arctic. This has been both accompanied by and, as we will show, accentuated by the government programs that have been made available to native peoples so that they may take advantage of the anticipated employment opportunities.

\section{THE POLICY CONTEXT}

The late 1960s and the 1970s constituted a period of rapid economic and political change in the Canadian North. In 1967, the Government of the Northwest Territories (GNWT) was moved to Yellowknife from Ottawa. Although its relationship with the Canadian central government remained essentially colonial, the GNWT expanded, as many functions gradually were devolved to it from Ottawa's Department of Indian Affairs and Northern Development (DIAND).

In 1968, the discovery of oil and gas at Prudhoe Bay, Alaska, created the expectation that similar finds would occur in Canadian territory. It also raised questions about the impact of nonrenewable resource development upon the northern environment and the native peoples. In 1969, the voyage of the tanker Manhattan through the Canadian Arctic Archipelago further complicated northern politics, for it directly challenged Canadian claims to sovereign jurisdiction over the area. Ottawa reacted in part by setting down in 1970 the northern pipeline guidelines, which were regarded by many as approval in principle for building a pipeline up the Mackenzie Valley (Dosman, 1975). Native northerners were concerned about imminent resource exploitation, a concern that came to be developed through the 1970s around the struggle against the pipeline and for the recognition of the land claims, which would allow indigenous people to control resource management and exploitation (Canada, 1977; Watkins, 1977; Abele, 1987). Moreover, at the beginning of this period the federal government's Indian policy was in turmoil. In June 1969, after a year of intense consultation with the bands and national organizations, Ottawa introduced a White Paper on Indian Policy. This was widely rejected as assimilationist and was abandoned by the government in 1971 (Weaver, 1981).

It was in this context that the central government prepared a new framework policy to guide northern development. Canada's North 1970-1980 was released in March 1972, though it was operative somewhat earlier (Canada, 1972). Although subsequent statements - and concrete policies, such as the National Energy Program - have had great impact on the N.W.T., Canada's North remained for 15 years the only comprehensive, official statement of Ottawa's stance toward the North and its peoples. The document embodied a re-ordering of priorities, with the straightforward recognition that the northerners came first. As the responsible minister put it,

Briefly, our objective has been to establish programs and policies that meet the needs of the people of the North, particularly the native people, programs and policies that maintain and protect the ecological balance and which ensure viable economic development of the Territories. The Government continues in the conviction that the needs of the people in the North are more important than resource development and that the maintenance of the ecological balance is essential. [Canada, 1973:4:40.]

Both native people and commentators have argued that the relative priorities laid down in Canada's North would not and have not guided northern policies; in particular, critics have argued that cultural preservation, land claims, and benefits for northerners have been secondary to resource extraction (Charley, 1973; Dosman, 1975; Moore and Vanderhaden, 1984). But, of course, northern "needs" are open to interpretation, both by Canadian governments and by native peoples themselves. In this connection, the existing distribution of views about economic development among indigenous peoples is important (Stewart, 1986). But also significant are programs that may alter native people's norms and values in the future, so that they may become more prepared to engage in new economic activities.

An important part of the new policy framework concerned "social improvement." Here, highest priority was placed on implementing a set of guidelines about providing jobs and job training in both the public and the private sectors. Policies would include measures to create employment for native peoples, to provide intensive job training, to quickly produce native practitioners in the professions and skilled trades, and to develop a cadre of trained public administrators. As well, however, traditional economic pursuits were to be encouraged, and the government was to encourage analogous jobs and training in occupations such as campsite supervisors, tourist guides, and game and fish wardens. The final social policy guideline concerned indigenous cultures: policies were to "Safeguard the culture (language, arts, handicrafts, traditional pursuits) of native peoples in the course of education, training, employment and community life; above all their right to choose what is to be preserved" (Canada, 1972:36).

But choice depends on what people bring to it. Native northerners who have experienced significant acculturation are obviously less likely to choose to pursue economic and social activities that are embedded in the "traditional" culture. Indeed, substantial acculturation may ultimately erode the sense of collective self-consciousness upon which depends the project of adapting southern techniques to northern needs and so forging renewed and dynamic native cultures (Stenbaek, 1987:309). As a respected Dene leader recognized, "Assimilation is not without some attraction, especially to some of the young and educated" (Erasmus, 1977:179). So we turn now to the question of whether employment training may have helped induce cultural change, not by its content but by its very structure.

\section{EMPLOYMENT TRAINING}

Employment training programs are not the only factors conducive to acculturation. The mass media are very important, as are work experience and formal education in primary and secondary schools. We focus here on job training because these programs may combine the effects of school and work. As well, the target group is interesting, since it consists of adults who have never entered or who have left the school system and who currently participate in the economy; hence, the social impact of job training programs may be relatively swift. Finally, this is a study of program implementation, and employment training programs in the N.W.T. have been numerous, varied, and flexible. Both the federal government and the GNWT have had 
a choice about how programs are designed and delivered. These programs can be structured so as to intensify the process of acculturation, by demanding new behaviour and inculcating new norms, or their design can accommodate existing norms, values, and attitudes and require fewer behavioural changes. In short, it is in the very framework of the programs, and not only in their content, that their impact and intent can be discerned. Although no comprehensive analysis of employment training programs is extant, their acculturative potential has been recognized by both native peoples and analysts. Hobart, for example, has described the social context of one corporate training program:

Virtually every feature of the program tended to enhance its broader socializational significance for the trainees: they were cut off from the role models, the reference groups, and the significant others which sustain the distinctive patterns of motivation, interest, and activity of Northerners. [Hobart, 1981:54.]

Our findings strongly suggest that the structure of government employment training programs has been such as to promote the acculturation of native peoples in the N.W.T. Three caveats should be noted at the outset, however. First, several programs analyzed here were open both to native people and to non-natives. This mitigates such responsibility for their impact as can be assigned to those who designed them; yet it does not affect the main thrust of our conclusions, which concern the effects on indigenous peoples of whatever programs were accessible to them. Second, the likely impact of other training programs offered in the N.W.T. cannot be assessed here. This study excludes the training offered independently by private firms, the cooperatives, and non-governmental organizations. (Nor do we analyze affirmative action/non-discriminatory hiring agreements made with firms.) On balance, we expect such training to be somewhat less conducive to acculturation than the set of programs studied here, though further research is desirable. The present focus is justified by the scale of the government effort and its continuity and by the fact that the programs analyzed were publicly funded by responsible governments with a clearly stated policy toward northern affairs. Finally, this study covers the period $1971-72$ to $1982-83$ only. The initial point coincides with both the new northern policy and the re-organization of training program delivery; the cutoff coincides with the assumption of much greater control over programming by the GNWT, its college system, and the native peoples themselves.

Employment training is defined as formal instruction designed to prepare a person for work in some specific occupation. Institutional training consists of courses or a mix of lessons and practical study, while on-the-job training refers to organized instruction (not trial-and-error learning or informal assistance from colleagues) within a production or work environment (Canada, 1973). Our study excludes, therefore, courses delivered in the primary and secondary school systems, as well as university courses, since these are geared to academic rather than vocational education. As well, we exclude short-term programs designed simply to provide work experience rather than training.

In Canada, education is the responsibility of the provincial governments. In vocational education, however, the central government has long been involved (Dupré et al., 1973). Programs are operated by both Ottawa and the GNWT, and although all institutional training is delivered by the latter, the governments share the costs of many programs. In 1971, new organizational arrangements came into full effect. The most signifi- cant change arose from the Adult Occupational Training Act of 1967, through which was established the Canada Manpower Training system. Under this arrangement, the central government purchased training courses from provincial and territorial institutions. For both institutional and on-the-job training, the Department of Manpower and Immigration (later CEIC - the Canada Employment and Immigration Commission) selected trainees, provided them an allowance, and paid the full cost of their instruction. Major institutional programs in place in 1971 included Vocational Skill Training, Basic Training for Skill Development, and Apprenticeship Training. Non-institutional programs included the Training in Industry Program and Training On-The-Job.

It is noteworthy that most CEIC programs that have operated in the North are designed for national application. But there is enough flexibility to allow for some local modifications in how they are implemented. In the N.W.T., many courses have been delivered at the Adult Vocational Training Centre in Fort Smith, which was given college status in 1981 and renamed Thebacha College (GNWT, 1983). It is overseen by the territorial Department of Education, which also offers some courses throughout the N.W.T. on an extension basis. The department has taken over from Ottawa some responsibility for educating technicians in areas such as the Classroom Assistant Training Program and the Public and Business Administration Program. Other units of the territorial government also have provided training: the Interpreter Corps Program was established by the Department of Information, the Department of Local Government set up the Hire North project in connection with highway construction, as well as the Observer/Communicator and Airport Maintainer programs, and the Department of Personnel ran In-Service Training in the territorial public service.

Other federal departments have been involved too. DIAND ran both specialized programs, such as Air Mechanic Training, and others designed to prepare indigenous people for public service employment, such as the Indian and Inuit Recruitment and Development Program. The Royal Canadian Mounted Police and the federal Public Service Commission have done the same.

Table 1 lays out the whole set of government-run employment training programs available in the N.W.T. between 1971 and 1983. It identifies the responsible government agency and provides a brief description of each. The programs have been characterized as institutional, industrial (on-the-job), and public-service oriented. Table 1 also presents the best available data on the number of N.W.T. residents trained each year and on the program expenditures. Much more complete accounts of every program are found in the appendices in McDermott (1985:120-173).

The overall story is clear. These are important programs, with about 1700 people per year enrolled (out of a 1981 N.W.T. population of 45700 ). There is a plethora of programs: new ones are added, and they are generally rather specialized; old ones rarely disappear. The bulk of the spending is concentrated on institutional training, but the public-service component has been rising in importance. The CEIC is still the lead funding agency, but the role of GNWT departments has increased steadily and substantially.

More detailed analysis of the changing programs and of their content is possible, but our interest here is in the way employment training has been delivered and in whether program structure has been conducive to acculturation among native trainees. To proceed along these lines it is essential to decompose pro- 
TABLE 1. Employment training programs delivered in the Northwest Territories, 1971-83: descriptions, expenditures and numbers of trainees ${ }^{\mathrm{a}}$

\begin{tabular}{|c|c|c|c|c|c|c|c|c|c|c|c|c|c|c|}
\hline No. & $\begin{array}{l}\text { Prograrn and agency } \\
\text { Description }\end{array}$ & $\begin{array}{c}1971-72 \\
\$ 000 \\
\text { No. }\end{array}$ & $\begin{array}{c}1972-73 \\
\$ 000 \\
\text { No. }\end{array}$ & $\begin{array}{c}1973-74 \\
\$ 000 \\
\text { No. }\end{array}$ & $\begin{array}{c}1974-75 \\
\$ 000 \\
\text { No. }\end{array}$ & $\begin{array}{c}1975-76 \\
\$ 000 \\
\text { No. }\end{array}$ & $\begin{array}{c}1976-77 \\
\$ 000 \\
\text { No. }\end{array}$ & $\begin{array}{c}1977-78 \\
\$ 000 \\
\text { No. }\end{array}$ & $\begin{array}{c}1978-79 \\
\$ 000 \\
\text { No. }\end{array}$ & $\begin{array}{c}1979-80 \\
\$ 000 \\
\text { No. }\end{array}$ & $\begin{array}{c}1980-81 \\
\$ 000 \\
\text { No. }\end{array}$ & $\begin{array}{c}1981-82 \\
\$ 000 \\
\text { No. }\end{array}$ & $\begin{array}{c}1982-83 \\
\$ 000 \\
\text { No. }\end{array}$ & No. \\
\hline \multicolumn{15}{|c|}{ Institutional } \\
\hline \multirow[t]{2}{*}{1} & Skill Training, CEIC & 291 & 308 & 669 & 400 & 514 & 917 & 874 & 1,311 & 853 & 1,528 & 1,408 & 2,472 & 1 \\
\hline & Pre-employment training and skill upgrading & 196 & 261 & 352 & 149 & 276 & 283 & 261 & 197 & 201 & 251 & 195 & 439 & \\
\hline \multirow[t]{2}{*}{2} & Basic Training for Skill Development, CEIC & 331 & 282 & $271^{b}$ & 615 & 650 & 669 & 782 & 480 & 254 & 351 & 338 & 447 & 2 \\
\hline & Academic upgrading for training programs & 223 & 238 & 143 & 229 & 349 & 399 & 356 & 140 & 101 & 97 & 71 & 177 & \\
\hline \multirow[t]{2}{*}{3} & Job Readiness Training, CEIC & & & NA & NA & NA & NA & NA & 262 & 215 & 254 & 452 & 393 & 3 \\
\hline & Life skills and job search techniques & & & NA & NA & NA & NA & NA & 104 & 104 & 69 & 88 & 100 & \\
\hline \multirow[t]{4}{*}{4} & Apprenticeship Training, ${ }^{c} \mathrm{CEIC}$ & 284 & 499 & 537 & 854 & 659 & 1,567 & 763 & 2,066 & 2,050 & 1,674 & 2,777 & 2,372 & 4 \\
\hline & Institutional and on-the-job training & 0 & 20 & 47 & 68 & 68 & 242 & 240 & 315 & 310 & 359 & 420 & 402 & \\
\hline & Sub-total ${ }^{\mathrm{d}}$ & 906 & 1,089 & 1,477 & 1,869 & 1,823 & 3,153 & 2,419 & 4,119 & 3,372 & 3,807 & 4,975 & 5,684 & \\
\hline & & 419 & 519 & 542 & 446 & 693 & 924 & 857 & 756 & 716 & 776 & 664 & 1,118 & \\
\hline \multirow[t]{2}{*}{5} & Air Mechanics Training, DIAND & 29 & 51 & 47 & 73 & 41 & 59 . & 53 & 40 & 55 & 41 & 99 & 125 & 5 \\
\hline & Apprenticeship training in air mechanics & 7 & 12 & 10 & 14 & 7 & 9 & 7 & 5 & 6 & 4 & 8 & 10 & \\
\hline \multirow[t]{2}{*}{6} & Observer/Communicator Training, D.L.G. & & & & & 30 & 63 & 96 & 192 & 262 & 301 & 291 & 306 & 6 \\
\hline & Training for natives for jobs in arctic airports & & & & & 6 & 12 & 15 & 15 & 12 & 14 & 19 & 16 & \\
\hline \multirow[t]{2}{*}{7} & Airport Maintainer Training, D.L.G. & & & & & 24 & 26 & 42 & 82 & 121 & 129 & 125 & 368 & 7 \\
\hline & Training for natives for jobs in arctic airports & & & & & 9 & 8 & 18 & 8 & 16 & 16 & 16 & 16 & \\
\hline \multirow[t]{2}{*}{8} & Certified Nursing Assistant Program, D.Ed. & 50 & 68 & 75 & 63 & 139 & 157 & 81 & 193 & 218 & 223 & 296 & 510 & 8 \\
\hline & Institutional and clinical training for CNAs & 12 & 16 & 16 & 12 & 24 & 24 & 23 & 24 & 24 & 22 & 24 & 22 & \\
\hline \multirow[t]{2}{*}{9} & Dental Therapist Training, D.Ed. & & 72 & 71 & 47 & 116 & 144 & 249 & 241 & 191 & 223 & 296 & 510 & 9 \\
\hline & Institutional and clinical training for DTTs & & 17 & 15 & 24 & 20 & 22 & 33 & 30 & 21 & 22 & 24 & 22 & \\
\hline \multirow[t]{2}{*}{10} & Classroom Assistant Training, D.Ed. & 168 & 169 & 141 & 52 & 116 & 207 & 226 & 80 & 91 & 122 & 185 & 232 & 10 \\
\hline & Institutional training for CAs & 40 & 40 & 27 & 25 & 20 & 30 & 10 & 11 & 10 & 12 & 15 & 10 & \\
\hline \multirow[t]{2}{*}{11} & Teacher Education Program, D.Ed. & 130 & 178 & 197 & 214 & 215 & 211 & 256 & 257 & 327 & 406 & 346 & 580 & 11 \\
\hline & Institutional training for northem teachers & 31 & 42 & 42 & 41 & 37 & 32 & 34 & 32 & 36 & 40 & 33 & 25 & \\
\hline \multirow[t]{2}{*}{12} & Renewabie Resource Management Program, D.Ed. & & & & & & & 113 & 209 & 255 & 284 & 370 & 557 & 12 \\
\hline & Institutional training in resource management & & & & & & & 15 & 26 & 28 & 28 & 28 & 24 & \\
\hline \multirow[t]{2}{*}{13} & P.B.A., D.Ed. & & & & & & & & & & & & 278 & 13 \\
\hline & Institutional training in public administration & & & & & & & & & & & & 12 & \\
\hline \multirow[t]{6}{*}{14} & Social Services Program, D.Ed. & & & & & & & & & & & & 278 & 14 \\
\hline & Institutional training in social work & & & & & & & & & & & & 12 & \\
\hline & Sub-total ${ }^{e}$ & 374 & 538 & 531 & 449 & 681 & 867 & 1,216 & 1,294 & 1,520 & 1,729 & 2,008 & 3,744 & \\
\hline & & 90 & 127 & 110 & 116 & 123 & 137 & 155 & 151 & 153 & 158 & 167 & 169 & \\
\hline & Total & 1,280 & 1,627 & 2,008 & 2,318 & 2,504 & 4,020 & 3,635 & 5,414 & 4,892 & 5,537 & 6,983 & 9,428 & \\
\hline & & 509 & 646 & 652 & 562 & 816 & 1,061 & 1,012 & 907 & 869 & 934 & 941 & 1,287 & \\
\hline
\end{tabular}

Industrial

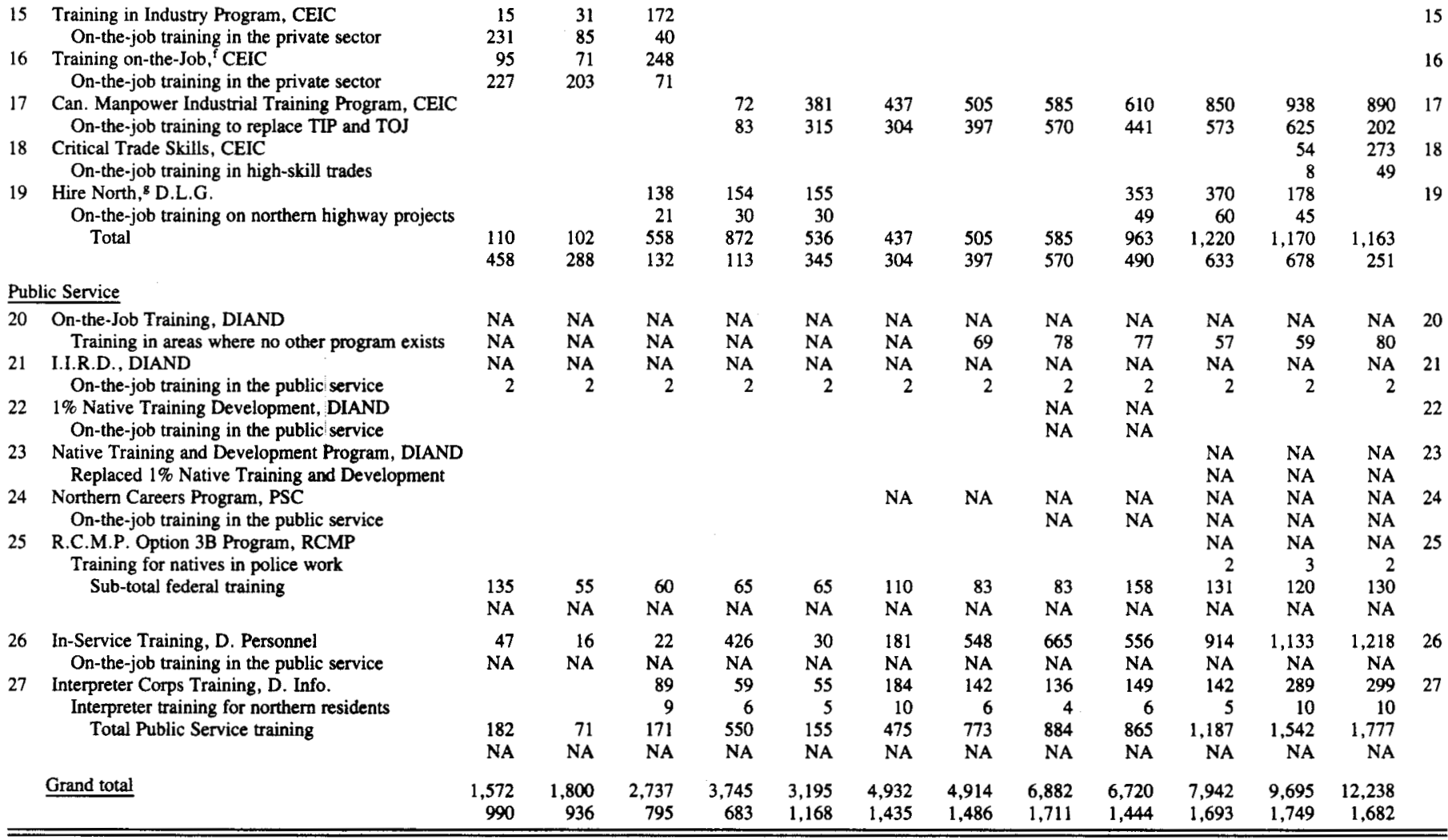

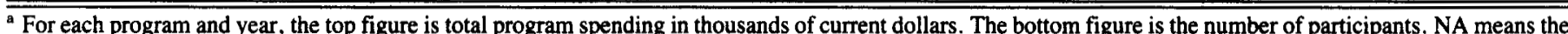

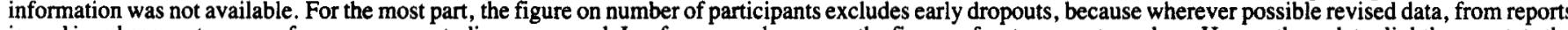

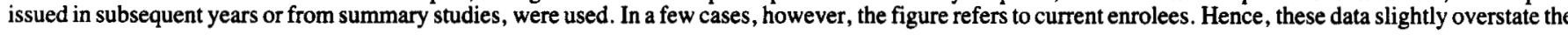


gram delivery. In the discipline of public administration, the study of policy implementation has become well developed (Pressman and Wildavsky, 1973; Berman, 1978; Sabatier and Mazmanian, 1981). This literature builds upon the proposition that the real impact of programs as implemented may be very different from that envisaged in formal policy goals, because of the way programs are designed and the mechanisms through which they are delivered. Here, we bring to bear on implementation and program structures the findings of sociologists and anthropologists about acculturation.

\section{MEASURING THE LATENT EFFECT OF PROGRAMS}

Although change in the N.W.T. was rapid over the 1971-83 period, there are at least five relevant aspects in which members of contemporary native cultures continue to differ generally from members of the mass North American culture. These are language, relationship to the land, the scheduling of activities (daily and annual), and the size of community of residence. Each of these elements corresponds to a facet of program delivery. Hence, every program can be assessed in these terms in order to determine its propensity to induce cultural change among native trainees.

\section{Language}

Different languages insulate cultural communities. Some analysts of the N.W.T. social mosaic stress language as a component of cultural identity and of social membership itself: language use can identify an individual as a member of a "cultural nation" (Sparham, 1979). Others push the argument further, to stress that the very survival of native languages assures "the maintenance of a particular philosophy and a particular mode of thought"' (Lambert, 1978:181-182). Without opening up deep questions about intercultural translatability (which have much occupied Canadians), we may nevertheless agree with Anderson and Frideres (1981:38) that linguistic change among members of an ethnic group or a nation can serve as "an indication of acculturation and assimilation."

Employment training programs can be delivered in English or in native languages. The first is more likely to promote acculturation.

\section{Sector}

While "traditional" indigenous socio-economic patterns have in fact been transitional for a very long time in the N.W.T., the native peoples have retained a special relationship with the land. There is, for instance, a widespread view that land is held communally, and hunting, trapping, and fishing are very common pursuits. Some analysts argue that wage labour itself is socially destructive, not only because it concentrates wealth but also because it divides the employed from the apparently poor who tend to rely on harvesting wildlife (Asch, 1979). Others contend that employment in non-renewable resource industries, which may damage the land, is disruptive: "some natives have feelings of betrayal of 'their people', particularly when they accept wage employment with a large development project" (Hobart, 1982:52).

It is clear that any wage labour can conflict with traditional activities that are still highly valued. Any new skills imparted tend to draw trainees into the southern socio-economic system. But employment training programs could be targetted toward occupations that are relatively compatible with renewable resourc-

number of graduates and understate the number of initial enrolees. Participants include both native and non-native enrolees. Many programs were affirmative-action programs open only to native peoples (defined as Indian, non-status Indian, Métis and Inuit). Such programs are those in rows 5, 6, 7, 10, 11, 20-25 inclusive, and 27. In 1982-83, these accounted for about $10 \%$ of all participants. Throughout the period, the programs in rows 1-4 accounted for the bulk of participants, but no systematic data on the ethnicity of trainees were kept. Our best estimates, based on interviews and information about participants' home communities, are that slightly over $50 \%$ of trainees throughout the period were native people; over time, native completion rates have risen, and native enrolment in Apprenticeship Training (row 4) has also risen proportionately. In industrial programs, with the exception of that in row 18 , at least $50 \%$ of trainees were native people. In summary then, it is safe to say that at least two-thirds of all participants in these programs over the 1971-83 period were native northerners.

b From 1973-74 to 1977-78, the expenditure estimates for Basic Training for Skill Development include expenditures on Job Readiness Training. See also note (d).

c Apprenticeship Training expenditures for 1971-72 to 1977-78 are from source 13. Other years were extrapolated using the federal government contribution to Apprenticeship Training and the number of trainees as baselines (sources 1 and 2).

This represents the estimated federal and territorial expenditures on Canada Manpower Training Program sub-programs. The estimates for lines 1, 2, and 3 are based on the fact that the federal contribution represents $70 \%$ of the actual training costs (source 3).

e For the programs on lines 5 through 14, expenditure breakdowns are not available. The sub-total was found by subtracting Canada Manpower Training Program expenditures from the total expenditure on institutional, vocational, and occupational programs, less capital spending and spending on adult education classes. Program estimates were then made. First, the per-student cost of Air Mechanics Training was taken as equal to the cost of Apprenticeship Training. The joint cost of the Observer/Communicator and Airport Maintainer programs was available (source 11); two-thirds of expenditures were allocated to the former course, which is longer. With these estimates subtracted from the sub-total, the remainder was split among the remaining similar programs (lines 8-14) according to the number of trainees in them each year.

f The Training-On-The-Job Program estimates were derived by multiplying the number of trainees by the average cost per student in the Training in Industry Program, which is similar.

8 Estimates are based on data on training hours and trainee numbers from source 9.

Sources:

1. Canada. Employment and Immigration Commission. Annual Reports, 1970-83.

2. Canada. Employment and Immigration Commission. Annual Statistical Bulletin: Canada Manpower Training Program, 1976-83.

3. Canada. Statistics Canada. Decade of Education Finance 1970-71 to 1979-80. Cat. 81-560 (Ottawa: 1983).

4. Canada. Statistics Canada. Financial Statistics of Education, 1970-83.

5. Canada. Department of Indian Affairs and Northern Development. Annual Reports, 1970-83.

6. Canada. Department of Indian Affairs and Northern Development. Advisory Committee on Northern Development. Government Activities in the North, $1970-83$.

7. Canada. Department of Indian Affairs and Northern Development. Vocational Training Section. (A. Barry Roberts Consultants Limited.) The Training of Northern Air Mechanics. Mimeographed. (1982.)

8. Government of the Northwest Territories. Department of Information. Annual Reports, 1970-83.

9. Government of the Northwest Territories. Department of Economic Development and Tourism. (Interdisciplinary Systems Limited.) Technical Report: Hire North Evaluation. Mimeographed. (1981.)

10. Government of the Northwest Territories. Department of Education. Education Programs and Evaluation Division. (Echo L.R. Lidster.) Some Aspects of Community Adult Education in the Northwest Territories of Canada 1967-1974. Mimeographed. (1978.)

11. Government of the Northwest Territories. Department of Finance. Annual Report of Territorial Accounts, 1970-83.

12. Government of the Northwest Territories. Department of Finance. Estimates, 1970-83.

13. Government of the Northwest Territories. Department of Finance. Evaluation of Apprenticeship Program. Mimeographed. (1978.)

14. Government of the Northwest Territories. Department of Personnel. In-Service Training Program Statistics from April 1973 to6 July 1983. Mimeographed. (1983.) 
es, the land, and traditional pursuits. If they are not, we will consider them likely to promote cultural change.

\section{Daily Scheduling}

North American society generally requires the acceptance of a daily ordering of events. Work, school, and even many recreational activities are strictly scheduled to allow formal organizations to function efficiently (Inkeles, 1983). In native societies in Canada, linear time planning generally is not so rigorous. Brody (1981) has described brilliantly the unhurried, consensual fashion in which activities are set in motion among Indian hunters in British Columbia, and similar decisions about hunting and recreation remain relatively open and flexible in the N.W.T.

In delivering employment training programs, scheduling can accommodate this cultural pattern or not. Rotational training schedules and voluntary participation in seminars are two possibilities, but the major alternative in use is modular learning, which allows the trainee to work at an individual pace. Programs with this structure we consider to be accommodative of existing cultural traits rather than conducive to acculturation.

\section{Annual Scheduling}

In the N.W.T., the annual round of resource harvesting is still vital to some native people, and many others favour a pattern of occupational pluralism in which hunting, fishing, and gathering are significant both socially and economically. Training programs that demand attendance at fixed periods will disrupt these activities, as will those that span several seasons (Rushforth, 1977; Kakfwi and Overvold, 1977). Since harvesting seasons overlap and also vary geographically across the territories, it is impossible to design program schedules that are not disruptive to some extent. However, programs that are offered on a "when numbers warrant" basis offer trainees the opportunity to participate in them with minimal interference of their other pursuits. We consider this scheduling to be accommodative and other forms to be acculturative.

\section{Location}

Settlement patterns in the N.W.T. have altered significantly since the 1950 s, when the central government encouraged migration to permanent settlements through a variety of social and financial assistance programs (Canada, 1977). Particularly in the smaller communities, however, many practices characteristic of the established ways of life remained intact (Brody, 1975).

Most analysts agree that migration to large urban centres, even for a limited time, is powerful in promoting cultural change, for it separates individuals from the familiar milieu and exposes them to a host of new influences (Nagler, 1970, 1975). Lambert (1978) argues that migration is conducive to assimilation and that native people who continue to live on reserves tend to retain their cultural identity. This effect is likely to be weaker when migration is not permanent, but it will still operate, because of the great variety of new features to which adjustment must be made in the larger towns (Honigmann, 1975). Therefore we consider program delivery to promote acculturation when employment training is offered not in the smaller communities but either in the South or in larger centres to which trainees must migrate (Fort Smith, Yellowknife, Frobisher Bay - now Iqaluit — or Inuvik-Tuktoyaktuk).

\section{THE RESULTS}

Figure 1 displays a summary of the propensity of each program's delivery structure to promote acculturation among native trainees. The dark circles represent accommodative programs; the light ones those with high acculturation probability. As the legend shows, a highly acculturative program was one offered in English, in a non-traditional sector, with inflexible daily and annual scheduling, and only in the large towns or the South.

The overall picture is clear. Most programs have delivery structures that make no compromises with indigenous culture. This is particularly true of public-service training programs (with the exception of the Interpreter Corps, run by the GNWT), but industrial programs also have been strongly acculturative (excepting Hire North, which was intermittent and very close to the margin between training and employment). The core institutional programs run under the aegis of the CEIC contain the greatest number of components that accommodate existing cultural traits; but over the period there has been little movement toward increasing this tendency.

Some programs, however, have shifted away from a delivery structure likely to induce acculturation. This is true of Apprenticeship Training and Classroom Assistant Training (which came to be offered in native languages), and of the Teacher Education
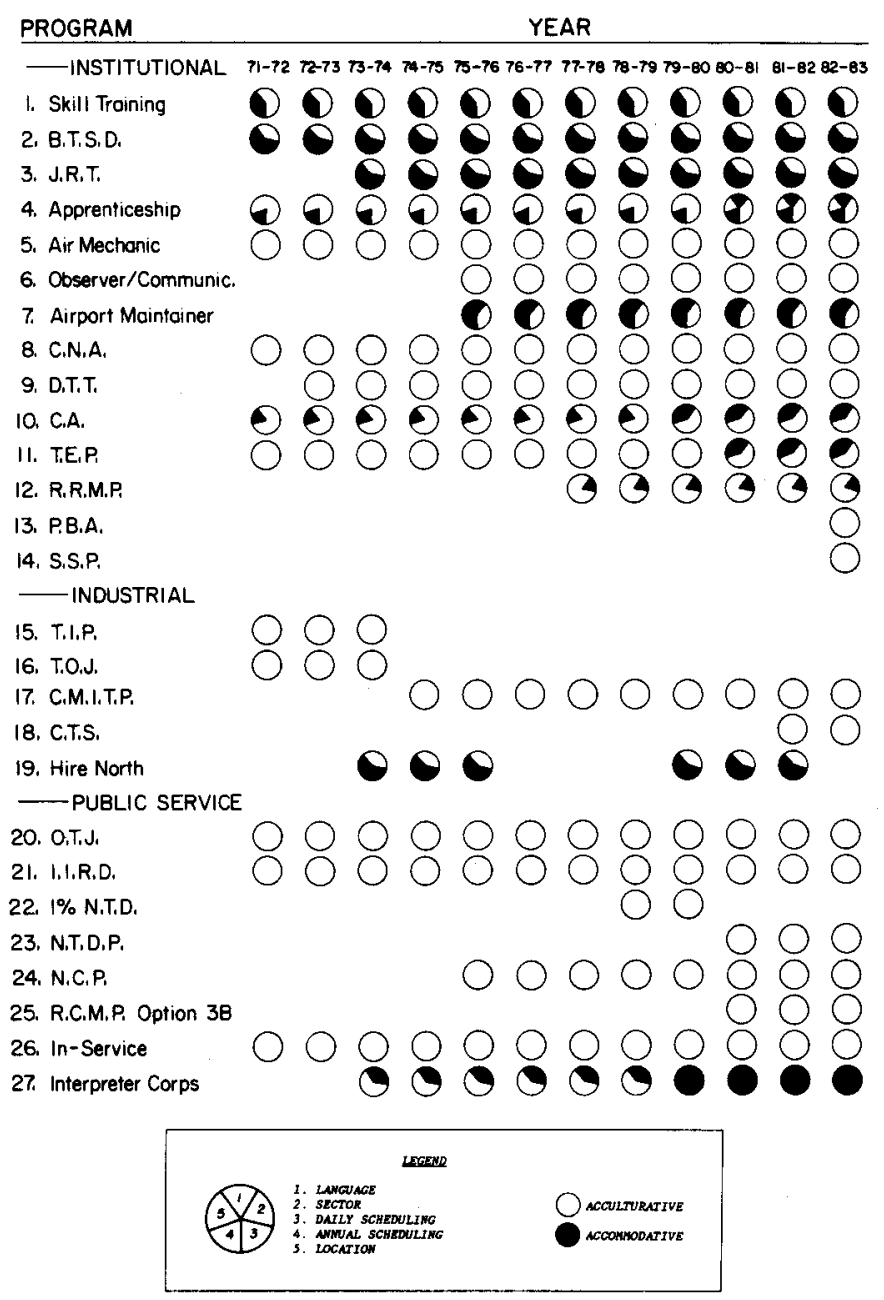

FIG. 1. Acculturative and accommodative components of employment training programs. 
Program. But this trend has been counterbalanced by the creation of new programs with an non-accommodative delivery structure, such as the Social Services Program and the Northern Careers Program. If each program has five structural components, one can summarize their impact by taking accommodative and acculturative components as a percentage of all components. The yearly figures are provided in Table $2 \mathrm{~A}$. Apart from the obvious move in the early 1970 s toward establishing more accommodative or culturally sensitive training programs, these figures reveal no general trend in the whole package of programs. Over the period analyzed here, the structure of employment training programs has generally been such as to induce acculturation among native enrolees.

Turning now to expenditures on these programs, as reported in Table 1 , it is obvious that the largest budgets were attached to the CEIC programs, which were all delivered under the rubric of the Canada Manpower Training Program. These account for almost two-thirds of all spending on institutional training, nearly all of the funds spent by governments for on-the-job training, and around 50 percent of the total expenditure on employment training. The smallest set of programs comprises federal public service training, which accounts for about 2 percent of spending. The GNWT contribution to training in the public sector is higher, having risen to about 15 percent of the overall total, and the GNWT presence in specialized institutional training has also increased substantially.

Table 2B breaks down expenditures according to the propensity of training programs to induce acculturation. Here we use a simple 0-5 scale of delivery structure, with low values indicating programs with structures that accommodate native people's cultural traits. The figures modify little the image of continuity conveyed by Figure 1, as the bulk of spending is on programs likely to induce acculturation. For most of the period, the existing variations are small enough to be caused by changing demand for programs whose structure remained constant. However, compared with the years when the Hire North program was not operating (1976-79) and expenditure shifted away from accommodative programs, the figures for recent years, and especially for 1982-83, reaffirm in financial terms the slight trend toward more cultural sensitivity, which was noticeable in Figure 1.

\section{DISCUSSION}

In Canada's Northwest Territories, most employment training programs operated by the central and the territorial governments, regardless of their skill content, have been implemented in such a way as to induce cultural change among native trainees and, ultimately, among the native population as a whole. This finding accords with Franks's (1984) more general conclusion about the delivery of government services in the N.W.T.: public administration has failed to recognize important cultural differences and has developed and delivered programs for indigenous peoples as though the clientele shared fully in the values, norms, and behaviour of modern North American society.

There were two exceptions to this pattern. Several institutional programs operated by the Canada Employment and Immigration Commission and delivered by the GNWT had structural components that were not strongly acculturative. These programs, however, had this character by coincidence, for they are national programs designed to provide entry-level skills and to help those so lacking in education or "life skills" that they cannot take further training or find and hold a job. Programs like Job Readiness Training are accommodative (in that they have flexible scheduling and do not require migration) because they are designed to reach out to those least attached to the permanent labour force, whether they live in Paquetville, New Brunswick, or in Spence Bay, N.W.T. Over the 1971-83 period, there has been no significant change in these programs to make them especially compatible with indigenous northern cultures.

The other exception to the acculturative structure of employment training delivery was a trend toward the end of the period to alter some components of existing programs. This was particularly apparent in four programs that came to be offered in native languages. In Apprenticeship Training, for example, "Inuktituk Special"' sub-programs began to be offered in housing maintenance, heavy duty mechanics, painting, and isolated community wiring. These recent changes follow, and may be a consequence of, the election of the Ninth Assembly of the N.W.T. in 1978 (Dacks, 1981). The Dene Nation (DN) lifted its boycott of the Assembly then, and there were elected several strong native members who were experienced leaders of organizations like the DN and the Inuit Tapirisat of Canada. It is interesting to note that new efforts have been concentrated on language and in areas like teaching, where talented early recruits presumably can diffuse new skills and values. In contrast, the programs training people for the public service, even the GNWT's own In-Service Training Program, make no compromises with the indigenous culture: designed to recruit "high potential natives" (Canada, n.d.:15), initiatives like the Indian and Inuit Recruitment and Development Program seem likely to promote significant acculturation among those very talented native people who will later fill important decision-making and administrative roles.

Throughout this analysis, it may appear that we have presumed that existing elements of indigenous cultures in the

TABLE 2A. Employment training program delivery: accommodative and acculturative components (\%)

\begin{tabular}{|c|c|c|c|c|c|c|c|c|c|c|c|c|}
\hline \multirow[b]{2}{*}{ Components } & \multicolumn{12}{|c|}{ Year } \\
\hline & $1971-72$ & $1972-73$ & $1973-74$ & $1974-75$ & $1975-76$ & 1976-77 & $1977-78$ & 1978-79 & $1979-80$ & $1980-81$ & 1981-82 & $1982-83$ \\
\hline Accommodative & 12 & 11 & 19 & 20 & 20 & 18 & 18 & 17 & 23 & 25 & 24 & 20 \\
\hline Acculturative & 88 & 89 & 81 & 80 & 80 & 82 & 82 & 83 & 77 & 75 & 76 & 80 \\
\hline
\end{tabular}

TABLE 2B. Percentage of total spending on employment training falling within each range of the acculturation scale

\begin{tabular}{lcccccccccccc}
\hline \hline & \multicolumn{10}{c}{ Year } \\
\cline { 2 - 10 } Scale range & $1971-72$ & $1972-73$ & $1973-74$ & $1974-75$ & $1975-76$ & $1976-77$ & $1977-78$ & $1978-79$ & $1979-80$ & $1980-81$ & $1981-82$ & $1982-83$ \\
\hline Least acculturative (0-1) & 0 & 0 & 0 & 0 & 0 & 0 & 0 & 0 & 2 & 2 & 3 & 3 \\
Moderately acculturative (2-3) & 40 & 37 & 43 & 33 & 44 & 36 & 37 & 33 & 31 & 42 & 34 & 55 \\
Most acculturative (4-5) & 60 & 63 & 57 & 67 & 56 & 64 & 63 & 67 & 67 & 56 & 63 & 42 \\
\hline \hline
\end{tabular}


N.W.T. are ipso facto worthy of preservation. We have not done so, however. The analysis rests on the supposition that cultural change works through changes in individuals, and that these may be induced not only by the obvious absorption of new knowledge and information but also more subtly, through the structures within which that absorption occurs. Organizing employment training in a culturally sensitive manner, we thought, might tend to preserve northern natives' opportunity to make a choice about their futures. It may be the case, though, that more accommodative programs have in fact a greater capacity to diffuse North American values and behaviour patterns, not through wrenching change but by a slower process of incorporation that might be deeper and more widespread because programs are more accessible.

In this view, change is coming surely - as it always has. The dilemma, as ever, is whether it will be rapid or gentle, imposed from without or chosen. In Canada's Northwest Territories, the most encouraging aspect of this dilemma, as it is now manifested in employment training, is that power to make decisions about government programs is shifting to the legitimate representatives of the indigenous peoples themselves. Their choices about economic development and cultural change will be worth close analysis in the future.

\section{ACKNOWLEDGEMENTS}

For supporting some research expenditures, we thank the Department of Indian and Northern Affairs and the University of Western Ontario Northern Research Committee. We are grateful, too, for the information provided by many officials and leaders of native organizations in the N.W.T. who agreed to be interviewed, and for helpful comments from Stefan Dupré, Randy Ames, Peter Clancy, and Frances Abele. P. Louise Gadbois kindly did the graphic work and Liz Jagdeo handled the tables.

\section{REFERENCES}

ABELE, F. 1987. Canadian Contradictions: Forty Years of Northern Political Development. Arctic 40(4):310-320.

ANDERSON, A.B., and FRIDERES, J.S. 1981. Ethnicity in Canada: Theoretical Perspectives. Toronto: Butterworths. $334 \mathrm{p}$.

ASCH, M. 1979. The Dene Economy. In: Watkins, M., ed. Dene Nation - the Colony Within. Toronto: University of Toronto Press. 47-61.

BERMAN, P. 1978. The Study of Macro- and Micro-Implementation. Public Policy 26(2):157-184.

BLICKENSTAFF, S. 1966. Training of Men for Steel in India. In: Elliot, W.Y., ed. Education and Training in the Developing Countries. New York: Praeger. 298-301.

BRODY, H. 1975. The People's Land: Eskimos and Whites in the Eastern Arctic. Markham, Ontario: Penguin Books. 240 p.

1981. Maps and Dreams: A Journey into the Lives and Lands of the Beaver Indians of Northwest Canada. Vancouver: Douglas \& McIntyre. 297

CANADA. 1972. Department of Indian Affairs and Northern Development. Canada's North 1970-1980. Ottawa: Information Canada. 40 p.

1973. House of Commons. Standing Committee on Indian Affairs and Northern Development. Minutes of Proceedings and Evidence. No. 4. 1 March 1973. Appendix C.

1977. Northern Frontier, Northern Homeland: The Report of the Mackenzie Valley Pipeline Inquiry. [The Berger Report.] Ottawa: Ministry of Supply and Services. 2 vols. 213 p., 268 p.

n.d. [1982.] Department of Indian Affairs and Northern Development,

Office of Native Employment. Resource Package for Managers: Minority Group Action Planning. Mimeographed. Yellowknife. In Arctic Institute Library, University of Calgary, Calgary, Alberta. 33 p.

CHARLEY, B. 1973. The Native People Reply. In: Pimlott, D.H., Vincent, K.M., and McKnight, C.E., eds. Arctic Alternatives. Ottawa: Canadian Arctic Resources Committee. 41-45.

DACKS, G. 1981. A Choice of Futures: Politics in the Canadian North. Toronto: Methuen. $226 \mathrm{p}$

DOSMAN, E.J. 1975. The National Interest: The Politics of Northern Development 1968-75. Toronto: McClelland and Stewart. $224 \mathrm{p}$.

DUPRÉ, J.S., CAMERON, D.M., MCKECHNIE, G.H., and ROTENBERG,
T.B. 1973. Federalism and Policy Development: The case of Adult Education in Ontario. Toronto: University of Toronto Press. $248 \mathrm{p}$.

ERASMUS, G. 1977. We the Dene. In: Watkins, M., ed. Dene Nation - the Colony Within. Toronto: University of Toronto Press. 177-181.

FRANKS, C.E.S. 1984. The Public Service in the North. Canadian Public Administration 27(2):210-241.

GNWT [Government of the Northwest Territories]. 1983. Thebacha College, A Historical Perspective. Fort Smith Regional Bulletin 4(11):n.p.

GUSFIELD, J.R. 1967. Tradition and Modernity: Misplaced Polarities in the Study of Social Change. American Journal of Sociology 72(4):351-362.

HIRSCHMAN, A.O. 1965. Obstacles to Development: A Classification and a Quasi-Vanishing Act. Economic Development and Cultural Change 13(4): 385-393.

HOBART, C.W. 1981. Performance of Native Trainees in an Apprenticeship Training Program. The Canadian Journal of Native Studies 1(1):33-58. 1982. Wage Employment and Cultural Retention: The Case of the Canadian Inuit. International Journal of Comparative Sociology 23(1-2):47-61.

HONIGMANN, J.J. 1975. Adaptations in Canadian Circumpolar Towns. In Müller-Wille, L., Pelto, P.J., Müller-Wille, Li., and Darnell, R., eds Consequences of Economic Change in Circumpolar Regions. Edmonton: Boreal Institute for Northern Studies. 149-162.

HOSELITZ, B.F. 1954. Problems of Adapting and Communicating Modern Techniques to Less Developed Areas. Economic Development and Cultural Change 2(1):249-268.

1959. Non-economic Factors in Economic Development. American Economic Review 47(2):28-41.

INKELES, A. 1974. The School as a Context for Modernization. In: Inkeles, A., and Holsinger, D.B., eds. Education and Individual Modernity in Developing Countries. Leiden: E.J. Brill. 7-23.

1983. Exploring Individual Modemity. New York: Columbia University Press. 376 p.

and SMITH, D.H. 1974. Becoming Modern: Individual Modernity in Six Developing Countries. Cambridge: Harvard University Press. 437 p.

KAKFWI, S., and OVERVOLD, B. 1977. The Schools. In: Watkins, M., ed. Dene Nation - the Colony Within. Toronto: University of Toronto Press. $142-148$.

LAMBERT, C. 1978. To Be Or Not To Be Indian: A Question Concerning Cultural Identity in Whitehorse, Yukon. In: Kovacs, M.L., ed. Ethnic Canadians: Culture and Education. Canadian Plains Studies No. 8. Regina: Canadian Research Centre. 177-187.

MCDERMOTT, P.T. 1985. The Modernization Effects of Employment Training Programs in the Northwest Territories. Unpubl. M.A. thesis, Department of Political Science, The University of Western Ontario, London, Ontario. $185 \mathrm{p}$.

MOORE, M. , and VANDERHADEN, G. 1984. Northern Problems or Canadian Opportunities. Canadian Public Administration 27(2):182-187.

NAGLER, M. 1970. Indians in the City. Ottawa: Canadian Research Centre for Anthropology. Saint Paul University. 107 p. da. $83 \mathrm{p}$

1975. Natives Without a Home. Don Mills, Ontario: Longman Cana-

NUNAVUT CONSTITUTIONAL FORUM. 1983. Building Nunavut: A Working Document with a Proposal for an Arctic Constitution. 38 p.

PRESSMAN, J.I., and WILDAVSKY, A. 1973. Implementation. Berkeley: University of Califomia Press. $182 \mathrm{p}$.

RUSHFORTH, S. 1977. Country Food. In: Watkins, M., ed. Dene Nation the Colony Within. Toronto: University of Toronto Press. 32-46.

SABATIER, P.A., and MAZMANIAN, D.A. 1981. The Implementation of Public Policy: A Framework of Analysis. In: Sabatier, P.A., and Mazmanian, D.A., eds. Effective Policy Implementation. Lexington, Massachusetts: Lexington. 3-35.

SACK, R. 1974. The Impact of Education on Individual Modernity in Tunisia. In: Inkeles, A., and Holsinger, D.B., eds. Education and Individual Modernity in Developing Countries. Leiden: E.J. Brill. 89-116.

SHILS, E. 1975. Centre and Periphery. Chicago: University of Chicago Press. $516 \mathrm{p}$.

SPARHAM, R.D. 1979. Language and the Equal Development of Societies. Report of the Study on Further Education in the Northwest Territories. Mimeographed. Yellowknife: Department of Education, GNWT.

STENBAEK, M. 1987. Forty Years of Cultural Change among the Inuit in Alaska, Canada and Greenland: Some Reflections. Arctic 40(4):300-309.

STEWART, D.A. 1986. Economic Development and Jobs: Changes in Perceptions in the Study Communities. Report 4-85. Norman Wells Socio-Economic Impact Monitoring Program. Ottawa: Indian and Northern Affairs. $34 \mathrm{p}$.

WATKINS, M. 1977. From Underdevelopment to Development. In: Watkins, M., ed. Dene Nation - the Colony Within. Toronto: University of Toronto Press. 84-99.

WEAVER, S.M. 1981. Making Canadian Indian Policy: The Midden Agenda 1968-1970. Toronto: University of Toronto Press. 236 p.

WILLNER, A.R. 1964. The Underdeveloped Study of Political Development. World Politics 16(3):468-482. 